\title{
The "Guaranteed Flow Working Group": A French evaluation of microhabitat component of IFIM based on habitat and brown trout population monitoring
}

\author{
C. Sabaton', Y. Souchon ${ }^{2}$, J.M. Lascaux ${ }^{3}$, F. Vandewalle ${ }^{3}$, \\ P. Baran ${ }^{4}$, D. Baril', H. Capra ${ }^{2}$, V. Gouraud ${ }^{4}$ F. Lauters ${ }^{5}$, P. Lim 6 , \\ G. Merle ${ }^{7}$ and G. Paty ${ }^{1}$
}

Corresponding Author: Catherine Sabaton, catherine.sabaton@edf.fr

\begin{abstract}
In the middle of the 1980s, the relicensing of numerous hydropower-plants led to widespread studies of the influence of discharge on trout populations. In particular, specific efforts were made to adapt and validate the PHABSIM microhabitat component of the Instream Flow Incremental Methodology (IFIM) to French rivers. IFIM is now widely used in France in impact studies for hydropower installations, to determine the instream flow to be recommended for the bypassed sections to meet the requirements of water resource legislation for salmonids. This paper presents the studies presently under way to validate this approach in biological terms. Initial feedback showed that the change from the original discharge in the bypassed section to the recommended value often allowed for a significant improvement in habitat. However, the population response in terms of change in biomass or population structure is not easy to identify. The problem is to determine the ultimate impact on a fish population due to an increase in the potential habitat. Our 4-year study of fish population dynamics on three different streams allows a better understanding of changes in populations. The results have illustrated the role of several factors which actually control the population density.
\end{abstract}

Key words. - IFIM, Phabsim, instream flow, biological validation, brown trout population

(1) EDF R\&D - LNHE 6 quai Watier 78400 Chatou France

(2) Cemagref, U.R. Biologie des Ecosystèmes Aquatiques Laboratoire d'Hydroécologie quantitative 3 bis quai Chauveau, CP220 69336 Lyon cedex 9 France

(3) ECOGEA 26 rue dels Pitbouls 31120 Lacroix Falgarde France

(4) Conseil Supérieur de la Pêche - Délégations Régionales de Dijon et de Montpellier : 23 Bd Doc. Jean Veillet 21000 Dijon France et 55 chemin du Mas de Matour 34790 Grabels France

(5) 21 avenue de l'Europe BP 4138040 Grenoble cedex France

(6) ENSAT, Laboratoire Environnement Aquatique Avenue de l'agrobiopole BP 10731326 Castanet Tolosan cedex France

(7) EDF - Pole Industrie - Mission Technique Hydraulique 1 place Playel 93283 Saint-Denis cedex France 


\section{INTRODUCTION}

One of the major challenges facing mankind in the $21^{\text {st }}$ century will be the preservation and sustainable management of water resources. The will to maintain a balance between preserving good ecological conditions in hydro-systems and providing for multiple uses of water has been made clear in French legislation. The French Fishing Law (1984), followed by the Water Law (1992), imposes new constraints with respect to bypassed sections downstream of hydropower plants, setting a minimum value for the guaranteed flow for all hydroelectric installations of $1 / 40^{\text {th }}$ of the mean annual flow, and at least $1 / 10^{\text {th }}$ of the mean annual flow at the time the license is renewed. The discharge effectively defined must "at all times, guarantee the survival, circulation and reproduction of the species living in the river before construction of the installation."

At the same time, the process of renewal of a number of Electricité de France hydropower licenses led, in the middle of the 1980 s, to significant efforts to study the influence of discharge on populations of trout, often a key species in rivers populated by salmonids. Because it was necessary to determine a discharge value that could meet the requirements in each specific case, it became clear that management tools were needed. It was at this time that habitat models were first studied in France, in particular the microhabitat component of the Instream Flow Incremental Meth- odology (called PHABSIM: in France also called the "microhabitat" methodology). Specific projects were conducted to validate and adapt the methodology to category 1 French rivers, reaches upstream of which hydropower installations are frequently found.

The microhabitat method is now widely used in France in impact studies of hydropower installations, to determine the discharge that must be maintained in bypassed sections to comply with the Water Law requirements. Preliminary evaluation shows that, at many power plants, increasing the discharge to respect the minimum value required by law often results in an increase in Weighted Usable Area (WUA). The problem now is to determine the ultimate impact on a fish population of the creation of potentially better habitat. That is, will the increase in WUA have an effect on the biomass, on density or growth, on the age class structure, or on some other variables?

Initial studies on several rivers with natural discharge show a significant correlation between the biomass of trout present in the river and the WUA for adults in low-water periods (Souchon et al, 1989). More recent studies on rivers in the Pyrenees (Baran, 1995; Lauters, 1995) have confirmed this relationship.

To validate IFIM in biological terms on reaches with power plants, experiments have been carried out on eight bypassed river reaches downstream of hydropower stations following an increase in the minimum instream 
flow. They are being conducted by a France-wide working group on "Guaranteed Flow" that groups experts from different research bodies, government agencies and Electricité de France (Merle and Eon, 1996).

The dynamics of trout populations in these reaches were studied for several years following the change in discharge. At the present time, efforts are being made to compare the evolution of these populations with the potential local carrying capacity given the new habitat conditions (as defined in the PHABSIM, Milhous et al, 1989), also taking into account the impact of other phenomena characteristic of the sites such as local hydrological features like flooding, management modes, degree of isolation of the environment, etc.

\section{MATERIAL AND METHODS}

\section{Experimental framework}

The overall experiment involves 8 sites which were chosen in 1994. Insofar as was possible, they were chosen to reflect the geographical diversity of the bypassed sections downstream of EDF hydropower plants; in the sites chosen, the nature of the physical habitat available to fish appeared to be most significant in relation to other factors which can impact the stocks.

A "baseline" state was described for each site in 1994. Reference sites (i.e. not in the reach subject to the change in discharge) and representative sites (characteristic of the bypassed section subject to the change in minimum instream flow) were selected to assess both physical change in the environment and evolution of the fish populations. At each site selected, preliminary measurement surveys provided a description of the physical and chemical characteristics of the environment (temperature and traditional water quality parameters). The global biological status was determined by sampling macroinvertebrate benthic fauna. The PHABSIM component of IFIM (Bovee, 1978) was applied using either the EVHA procedure developed by CEMAGREF (Ginot et al, 1998) or that proposed by EDF (Sabaton et al, 1995) in order to estimate WUA curves as a function of the discharge for the three stages in development of brown trout; a study of these curves enabled determining the minimum instream flow to be tested and the gain in habitat to be expected in relation to the previous instream flow. Electrofishing was used to inventory fish populations at the different sites for each individual mesohabitat (total fish biomass and density; for trout: size histograms and determination of the different age classes). Spawning habitats were inventoried and reproduction zones quantified (protocol found in Delacoste et al, 1993 and Delacoste, 1995) in order to identify any limitation occurring during this biological phase.

Figure 1 shows the location of the different sites: 4 in the Alps, one in the 


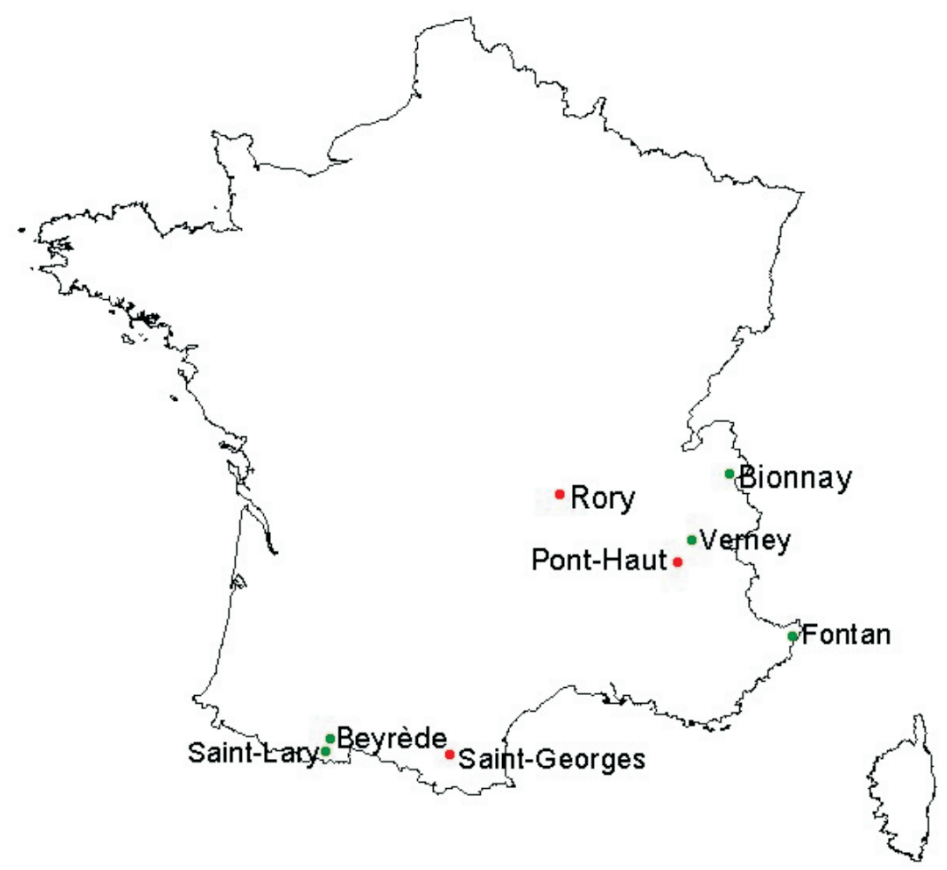

Fig. 1. - Localisation of the eight study sites

Massif Central region and 3 in the Pyrenees.

Following the increase in discharge in 1998, monitoring protocols were set up to follow environmental changes over a 4-year period, from 1999 to 2002, including:

- continuous temperature measurement,

- continuous measurement of discharge in bypassed sections,

- annual fish inventories for each mesohabitat,

- inventories of spawning habitats.

Halieutic surveys were also set up to evaluate the impact of fishing on the study areas.
After four years of monitoring, new surveys were performed to study water quality and macroinvertebrate benthic fauna, in order to update data on the ecosystem.

The microhabitat surveys were also repeated to see if there had been any change in the river morphology. The objective was to make sure there had been no major events capable of modifying the response of the river, in terms of physical carrying capacity, to the change in minimum instream flow.

The points developed in this paper are based on observations at 3 of the 8 test sites, which have made it possible to determine the characteristics of the main phenomena which appear to govern the dynamics of the different 


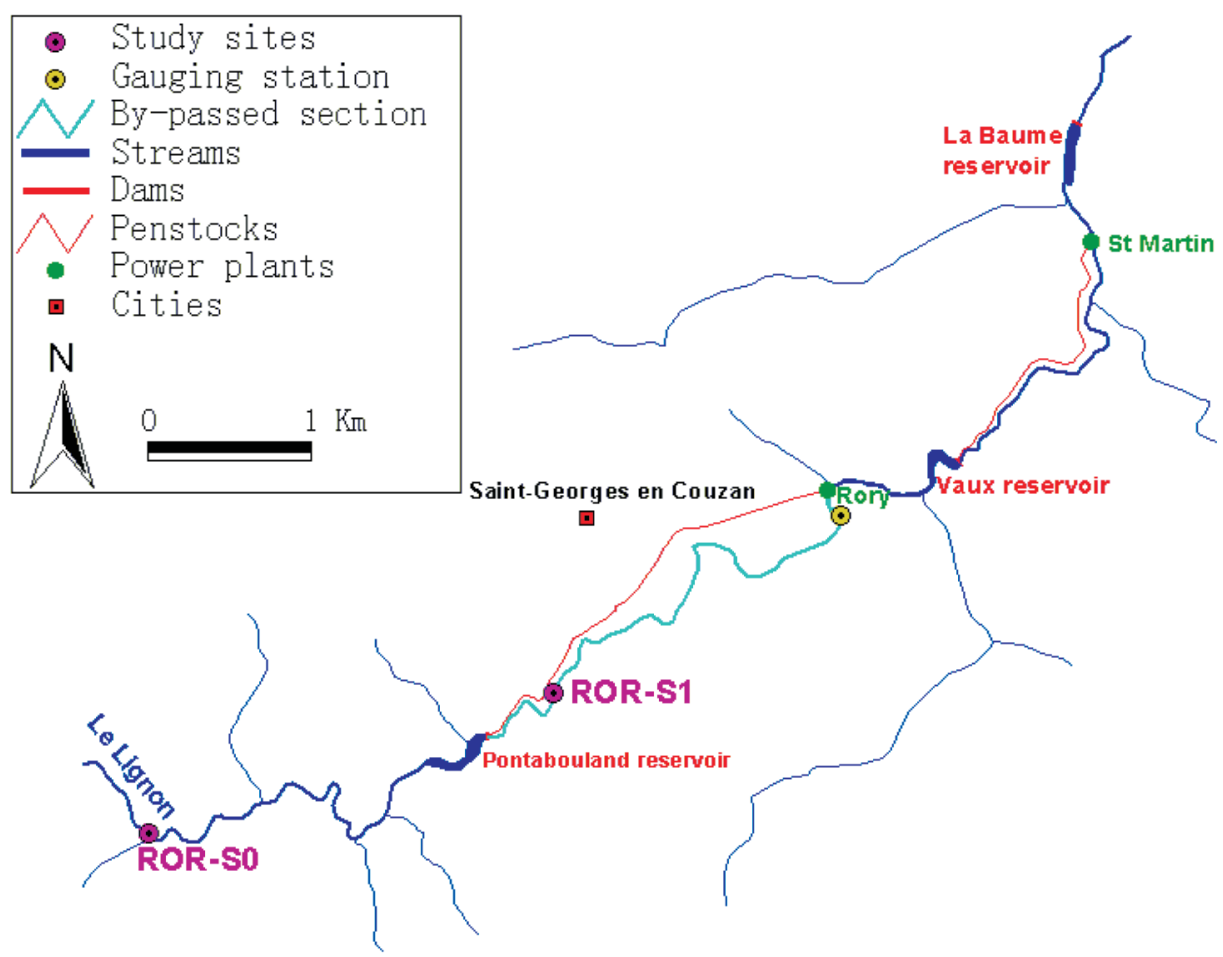

Fig. 2. - Site of Rory - Map of the river Lignon

populations observed. These three sites are: Rory on the Lignon du Forez in the Massif Central region, Pont-Haut on the Roizonne in the Alps, and Saint Georges on the Aude in the Eastern Pyrenees.

\section{The three typical sites}

Rory on the Lignon du Forez. The bypassed section of the Lignon at Rory (Figure 2) is $3.5 \mathrm{~km}$ long. Mean annual (M) flow is $2.87 \mathrm{~m}^{3} / \mathrm{s}$. The hydrologic regime is pluvio-nival (rain and snowmelt driven). Two test sites were established: ROR-S0, the refer- ence site upstream of Pontabouland dam, on the natural stretch of the Lignon, and ROR-S1 on the bypassed section.

The mean width of the river - after the increase in discharge for the new instream flow - is $9 \mathrm{~m}$ and its slope is $7.6 \%$ at the ROR-S1 site. The water of the Lignon is cool and of good quality, meeting the ecological requirements of trout.

Figure 3 shows the variation in WUA as discharge changed at ROR$S 1$, characteristic of the bypassed section. The minimum instream flow 


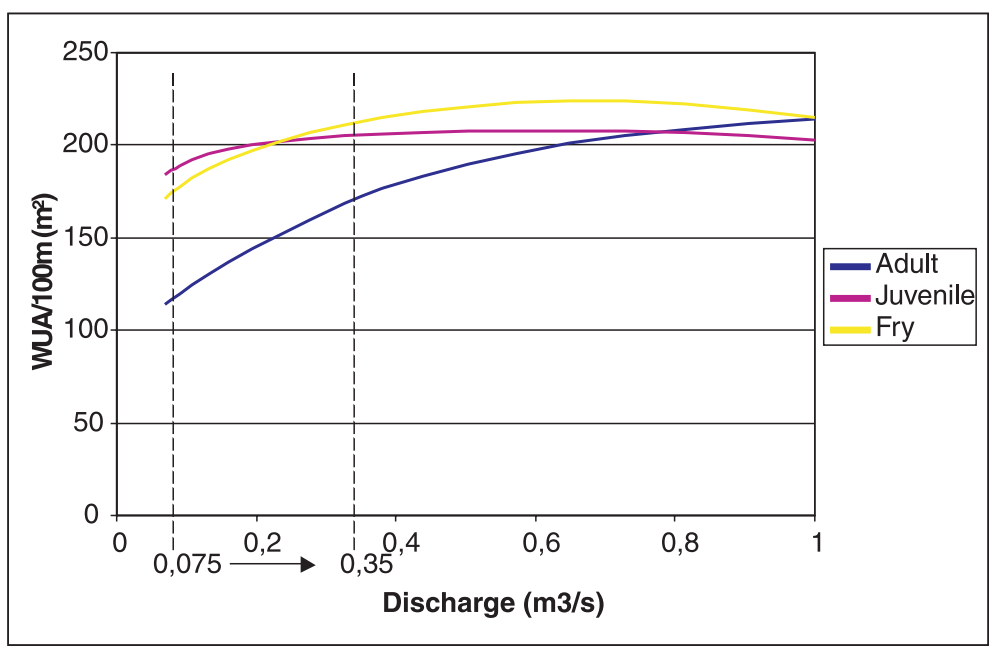

Fig. 3. - Site of Rory - WUA versus DISCHARGE for the brown trout - Three life stages

rose from $0.075(\mathrm{M} / 40)$ to $0.35 \mathrm{~m}^{3} / \mathrm{s}$ $(\mathrm{M} / 8)$ in October'98. This corresponds to an approximate $30 \%$ increase in WUA for adults.

Pont Haut on the Roizonne. The length of the bypassed section at Pont-Haut, on the Roizonne (Figure 4), is $3 \mathrm{~km}$. Mean annual flow is $2.4 \mathrm{~m}^{3} / \mathrm{s}$. The hydrological regime is nivo-pluvial. The reference site PONSO is upstream of the La Valette dam on a reach with natural discharge; PON-S1 is on the upstream part of the bypassed section of which it is representative.

The mean width of the river is $6.7 \mathrm{~m}$ after the increase in discharge and the slope is $3.9 \%$ at the PON-S1 site. In terms of temperature and physiochemical characteristics, the waters of the Roizonne satisfy the needs of trout.
Figure 5 shows the variation in WUA as discharge changes at PON$S 1$, characteristic of the bypassed section. Minimum instream flow rose from $0.070(\mathrm{M} / 40)$ to $0.28 \mathrm{~m}^{3} / \mathrm{s}(\mathrm{M} / 8)$ in March '99, causing an approximate increase in WUA for adults of $30 \%$.

Saint Georges on the Aude. The bypassed section of the Aude at Saint Georges (Figure 6) is $4.1 \mathrm{~km}$ long. Mean annual flow is $7.3 \mathrm{~m}^{3} / \mathrm{s}$ and the hydrological regime is nivo-pluvial, subject to the influence of upstream hydropower installations.

The STG-S0 reference site is upstream of Usson reservoir, also in a reach with minimum instream flow but at the end of the reach, with discharge significantly replenished by inflow from the intermediate watershed and tributaries of the Aude. Representative site STG-S1 is on the 


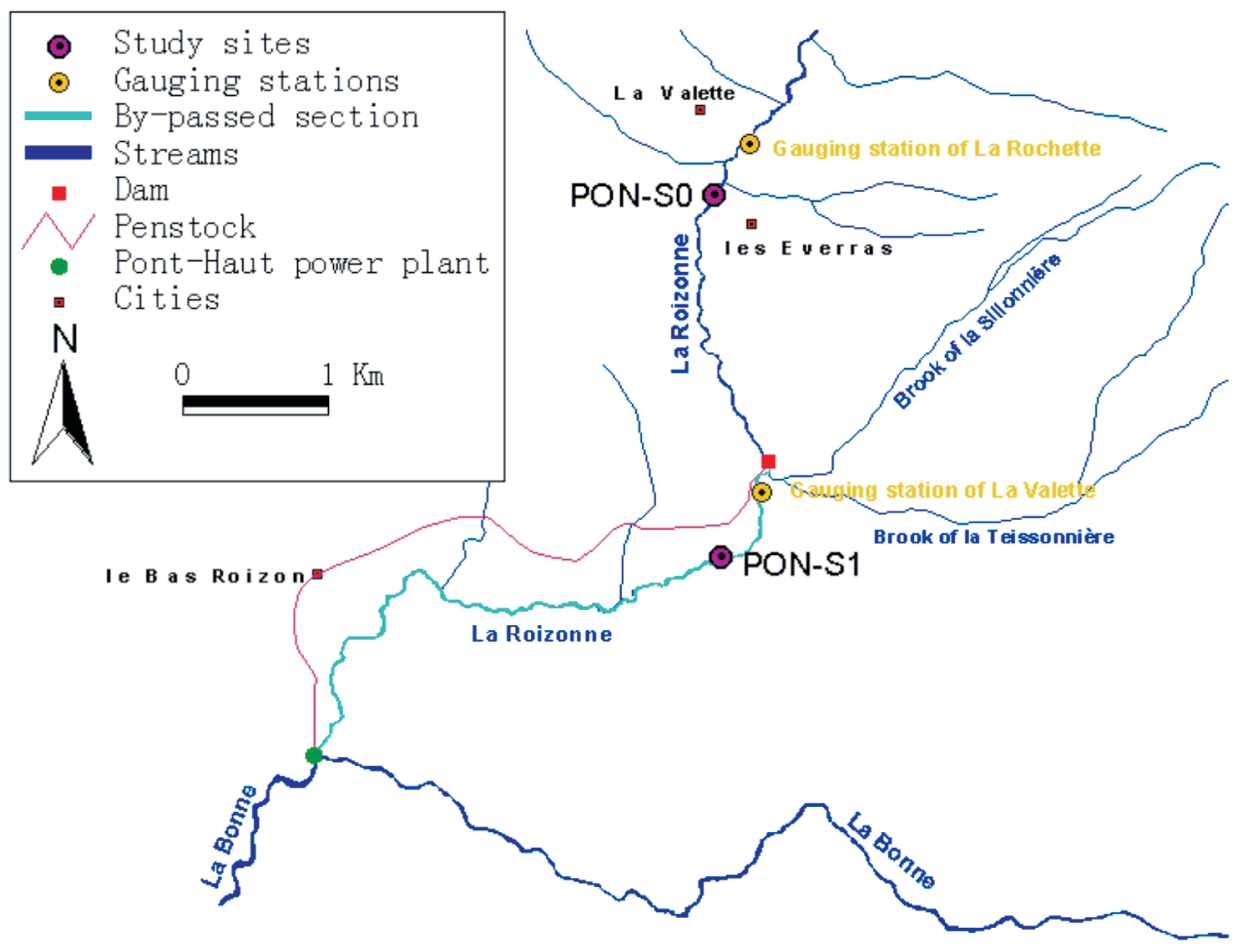

Fig. 4. - Site of Pont-Haut - Map of the river Roizonne

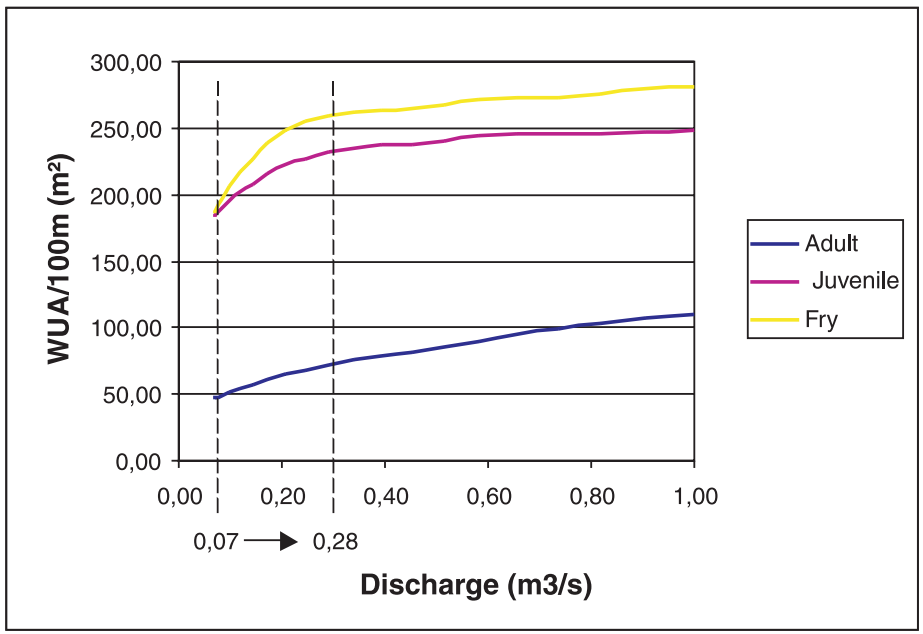

Fig. 5. - Site of Pont-Haut - WUA versus DISCHARGE for the brown trout - Three life stages 


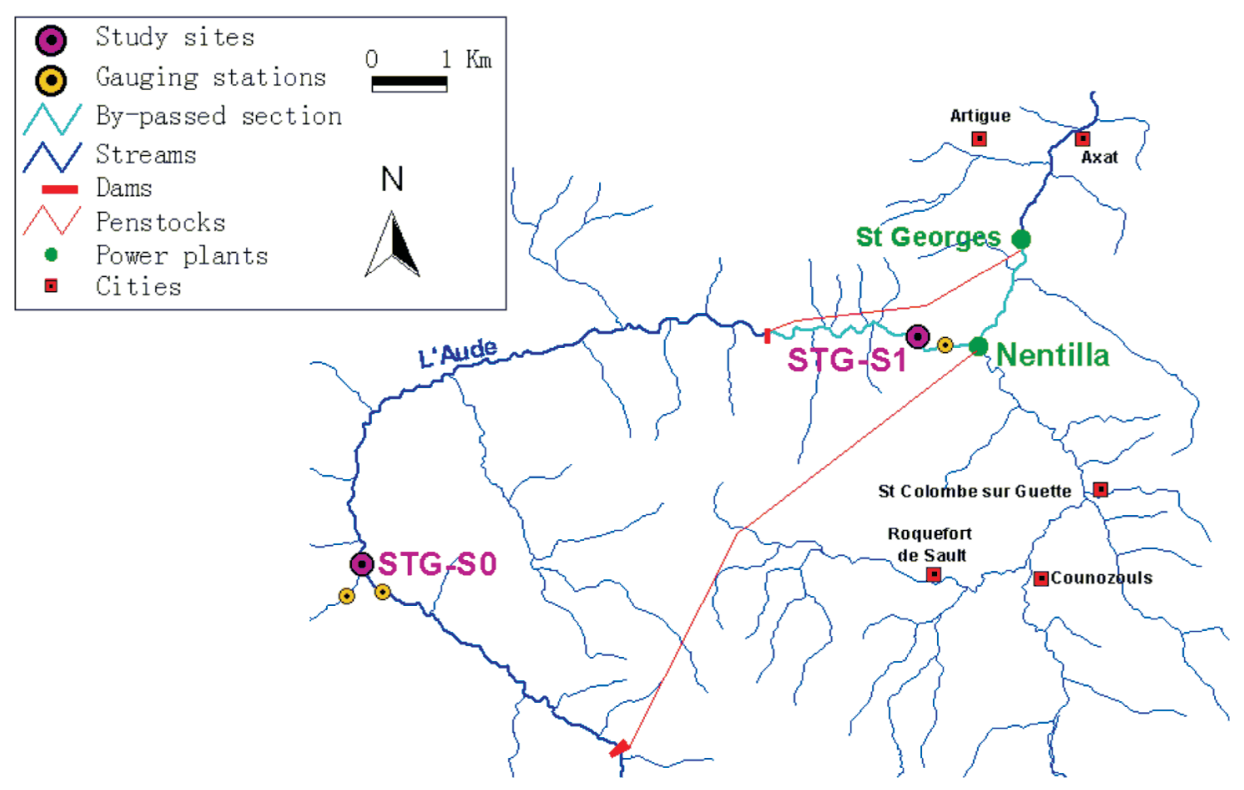

Fig. 6. - Site of St Georges - Map of the river Aude

upstream part of the Saint-Georges bypassed section. The mean width of the river is $11.5 \mathrm{~m}$ after the increase in discharge and the slope is $2 \%$ at STG-S1. Winter temperatures are relatively mild. While summer temperatures can reach $18.5^{\circ} \mathrm{C}$ some years, the thermal cycle of the Aude in this area corresponds globally to the needs of trout. Aude waters in the region are of good quality, both before and after the increase in discharge.

Figure 7 shows the variation in WUA as discharge changes. Minimum instream flow rose from 0.192 $(\mathrm{M} / 40)$ to $0.630 \mathrm{~m}^{3} / \mathrm{s}(\mathrm{M} / 12)$ in October' 98 , with a gain in WUA for adults on the order of $45 \%$.

\section{Analysis of the data}

Fish inventories have enabled studying the change in density and biomass of the different age classes subsequent to the increase in instream flow. Rates of occupancy (expressed in grams of adult fish $/ \mathrm{m}^{2}$ of WUA available to adults) give an idea of the ability of the populations to occupy the available habitat. These rates are calculated every year by comparing the adult biomass estimated from inventories with WUA for adults at the mean flow in low-water periods at sites with natural discharge, and with WUA for adults at the minimum instream flow rate in the bypassed sections. The underlying 


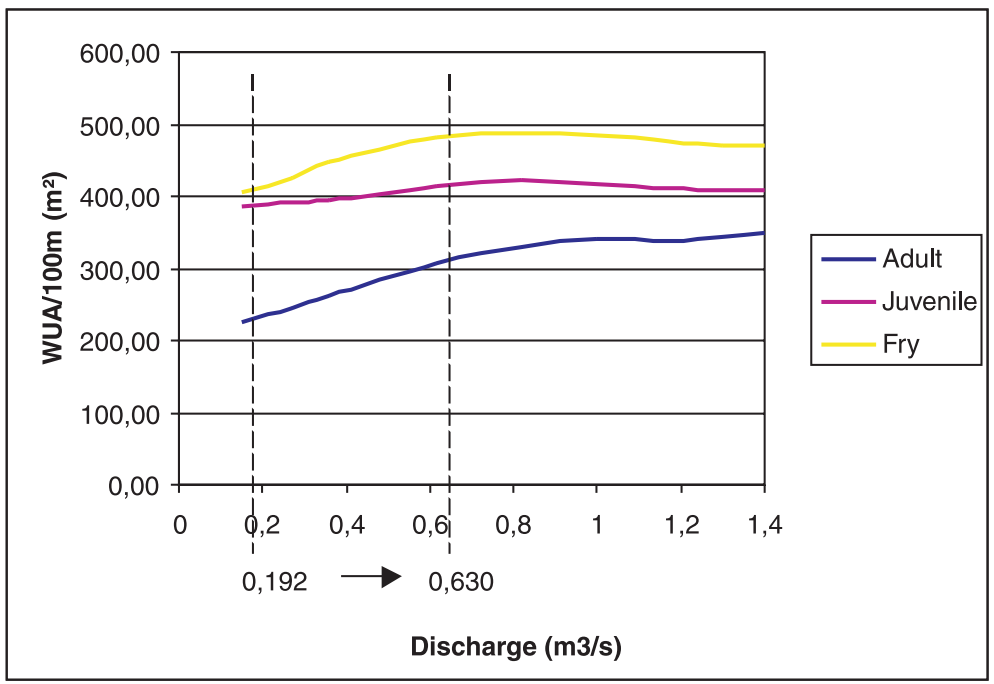

Fig. 7. - Site of St Georges - WUA versus DISCHARGE for the brown trout - Three life stages

hypothesis that biomass increases in proportion to an increase in carrying capacity (expressed by the WUA) would give equal occupancy rates before and after the increase in minimum instream flow, allowing time for the trout to re-establish balance in relation to the new potential of the habitat.

An analysis of discharge chronologies highlighted the hydrological episodes experienced by the different cohorts during the period of the study: periods in which minimum instream flow was maintained, periods of overflow, periods of strong flooding. Flood periods, potentially limiting for young fish, were analyzed by means of CUT curves (Capra, 1995).

Data on the reproduction phase for trout (density in spawning grounds, \% of the granulometry favorable to re- production) were compared to mean values found in neighboring basins in cases where the reproduction phase appeared to be limiting.

The effects of fishing (catch per unit effort, number of hours of fishing per kilometer per year, number of trout fished per year per kilometer of river) were also examined when they appeared limiting.

\section{RESULTS}

We shall begin by presenting the density and biomass of trout estimated at the time of inventories at each site, analyzing the discrepancies between the reference site and the site in the regulated reach and examining evolution over time, in particular after the increase in instream 
flow. Rates of occupancy will then be examined alongside the dynamics of the populations by studying evolution in the different age classes. This will point up the real impact of the increased discharge in comparison with the impact of other phenomena characteristic of each site.

\section{Evolution in trout density and} biomass at each of the three sites

Rory on the Lignon du Forez. While at reference site ROR-S0, trout density fluctuates between 1999 and 2002 (between 94 and 172 individuals/ $100 \mathrm{~m}$ - Figure 8a), it increases steadily over the same period at ROR-S1, from 87 individuals $/ 100 \mathrm{~m}$ in 1999 to 199 individuals/100m in 2002. Similarly, trout biomass tends to drop from 1999 to 2002 at ROR-S0 (from 6.5 to $4.1 \mathrm{~kg} / 100 \mathrm{~m}$ - Figure $8 \mathrm{~b}$ ) whereas it increases at ROR-S1 (from 4.7 to $6.5 \mathrm{~kg} / 100 \mathrm{~m}$ ). The population is more abundant at the reference site until 2000 , when it becomes more abundant in the bypassed section.

Pont-Haut on the Roizonne. The evolution in total density (Figure 9a) is remarkably similar at the two study sites, with a strong drop beginning in 1999 and a sharp rise in 2002.

With the exception of 2002, densities are slightly higher in the bypassed section than they are in the upstream reach. Biomass is also significantly higher (Figure 9b).

Saint-Georges on the Aude. While at STG-S0, trout density tends to in- crease between 1999 and 2002 (Figure 10a), it is relatively stable over the same period at STG-S1 in the bypassed section. Similarly, trout biomass increases consistently beginning in 1999 at STG-S0, while it remains stable at STG-S1. The population is always more abundant at the reference site (Figure 10b).

Impact of minimum instream flow on population dynamics, as compared with other factors

Gain in WUA and degree of isolation of the area: Rory site. Rates of occupancy were calculated for low-flow conditions at the reference site $(440 \mathrm{l} / \mathrm{s})$. They fall (Figure 11) in a range lower than what is generally found in France (between 30 and $65 \mathrm{~g} / \mathrm{m}^{2}$ of WUA - Souchon et al, 1989; Baran, 1995). They dropped along with the adult biomass in 2001 and 2002. Rates of occupancy in the bypassed section vary similarly, although a high value is found in 2002.

In the bypassed section, the biomass observed in 1999 is markedly higher than was found in 1995. This increase cannot be linked to the increase in minimum instream flow a few months earlier at this site with no tributaries and no possibility for colonization from downstream. The occupancy rates illustrated by the hatched bar (adult biomass in 1999 over WUA before the increase in discharge) give a better picture of the evolution in occupancy rates after the increase in discharge. Because the trout population does not react instantly to the 


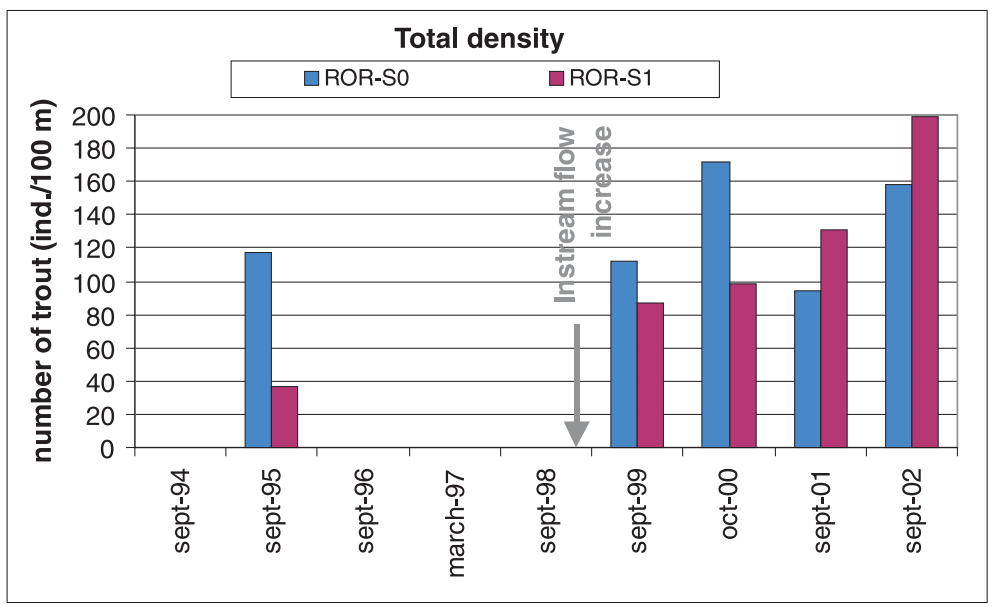

Fig. 8a. - Site of Rory - Density for each inventory - Comparison between reference site and site in by-passed section

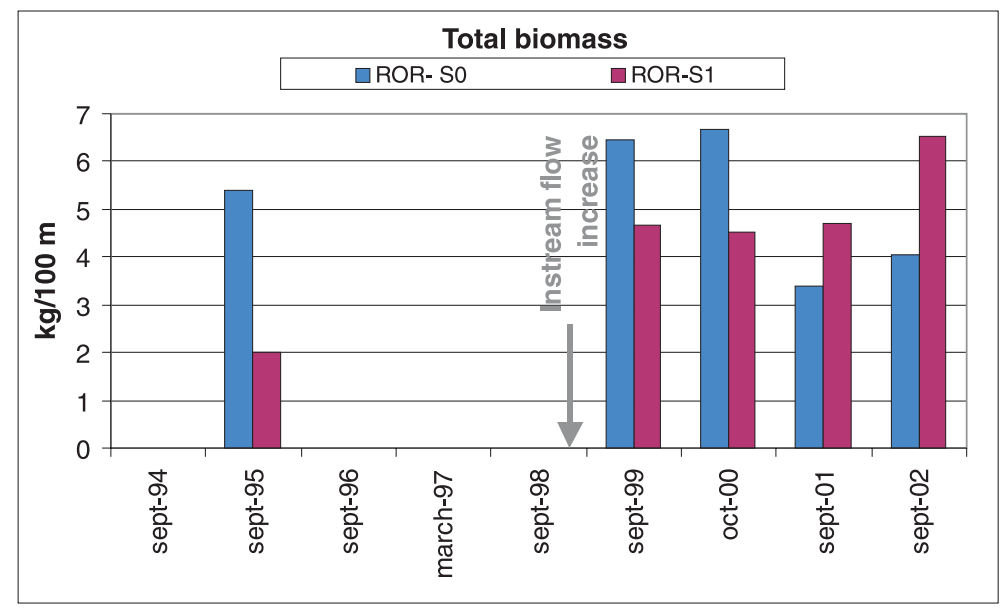

Fig. 8b. - Site of Rory - Biomass for each inventory - Comparison between reference site and site in by-passed section

new carrying capacity in the environment ( $40 \%$ increase in WUA), we first note a drop in the rate of occupancy of the habitat. It is only in 2002 that the occupancy rate returns to a value comparable to what it was before the increase in discharge: at this site, therefore, occupancy does tend to increase in proportion to the gain in habitat. 


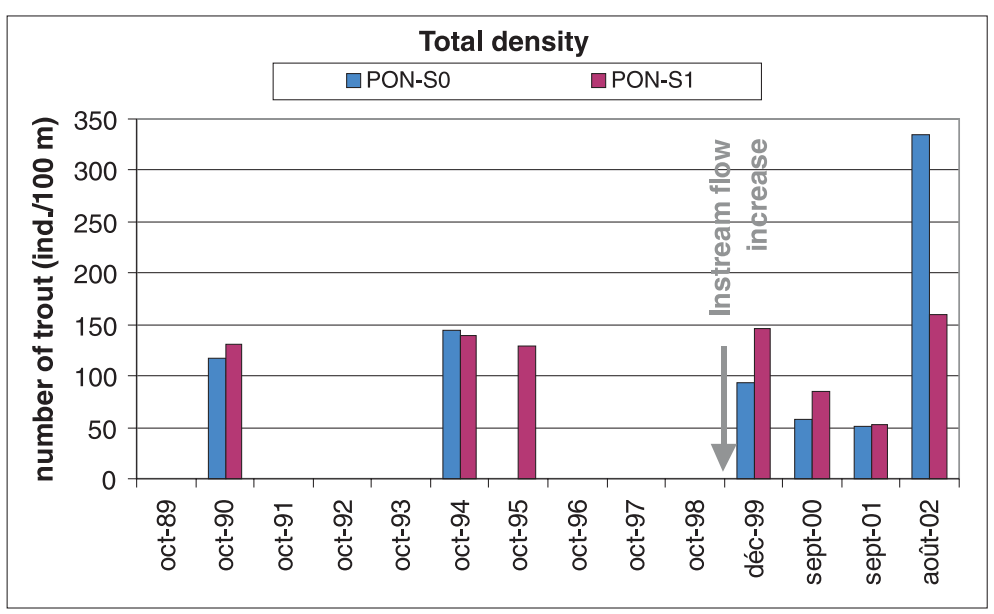

Fig. 9a. - Site of Pont-Haut - Density for each inventory - Comparison between reference site and site in by-passed section

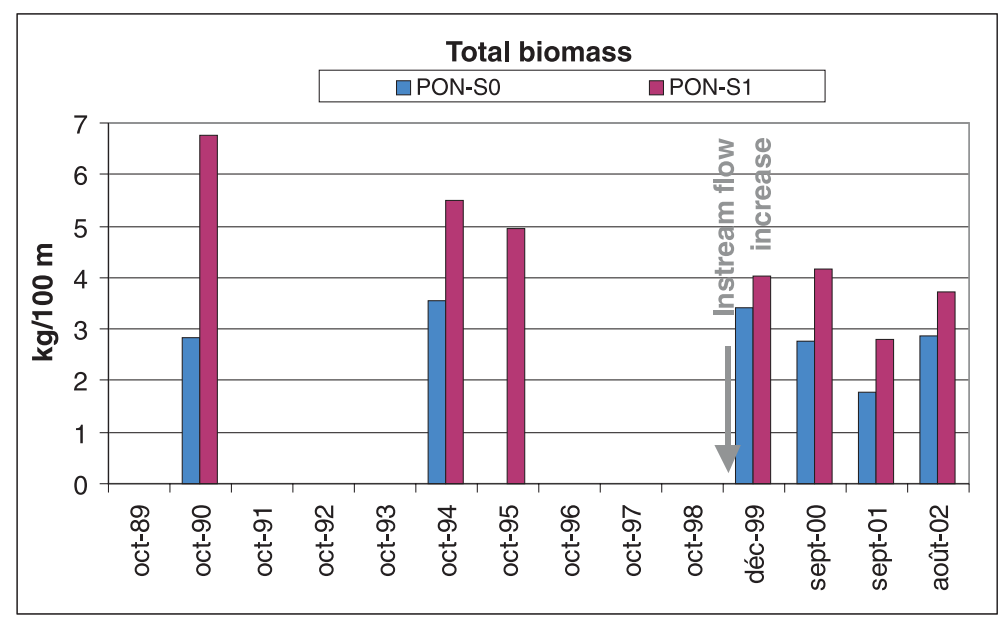

Fig. 9b. - Site of Pont-Haut - Biomass for each inventory - Comparison between reference site and site in by-passed section

A study of the cohorts (figure 12) shows that at both sites, the number of $1+$ individuals is close to, or even higher than the $0+$ in the previous year. The upstream reference site, ROR-S0, is in an open stretch of the
Lignon, where juveniles may come from upstream or from tributaries. The ROR-S1 site, on the other hand, is between two dams and tributaries are rare and of very moderate size in this reach. 


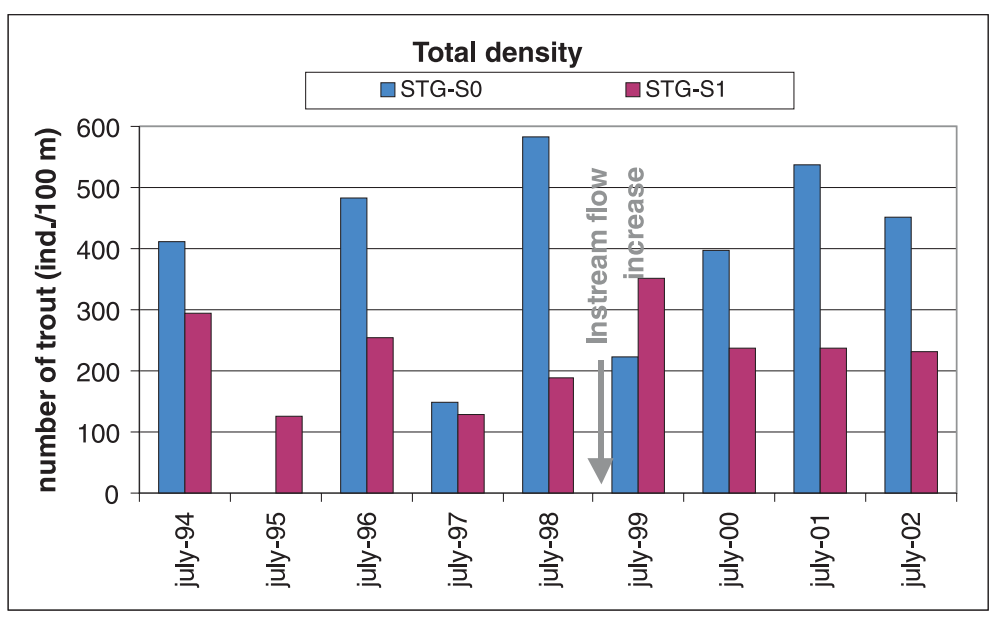

Fig. 10a. - Site of St Georges - Density for each inventory - Comparison between reference site and site in by-passed section

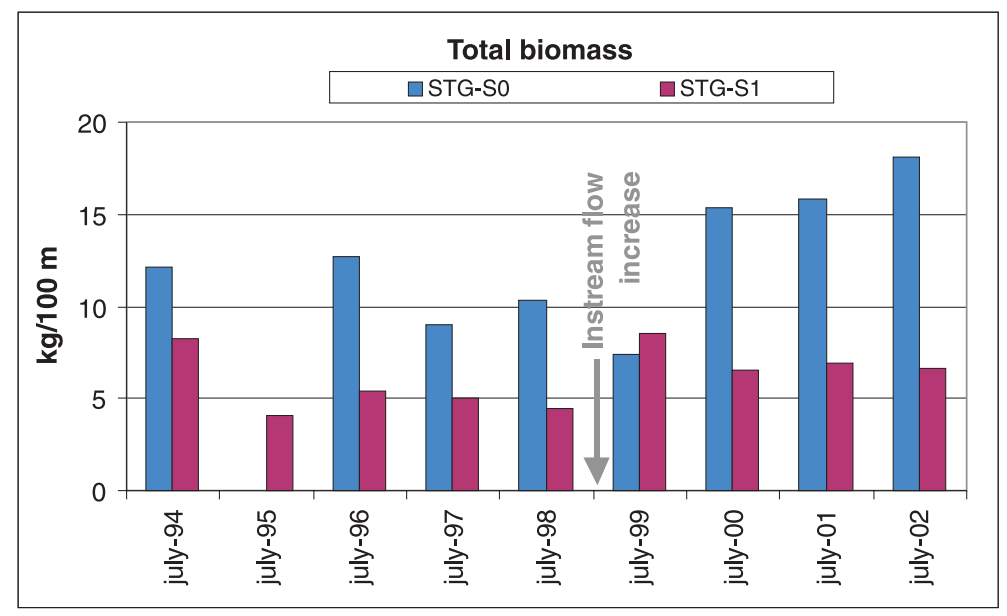

Fig. 10b. - Site of St Georges Biomass for each inventory - Comparison between reference site and site in by-passed section

Assuming a $50 \%$ morality rate between the 0+ class in one year and the $1+$ in the next, Table 1 shows the relatively close relationship between the surplus of juveniles and the num- ber of days of spill at Pontabouland dam between March and mid-November (the period during which the waters of the Lignon are at a temperature favorable to downstream mi- 

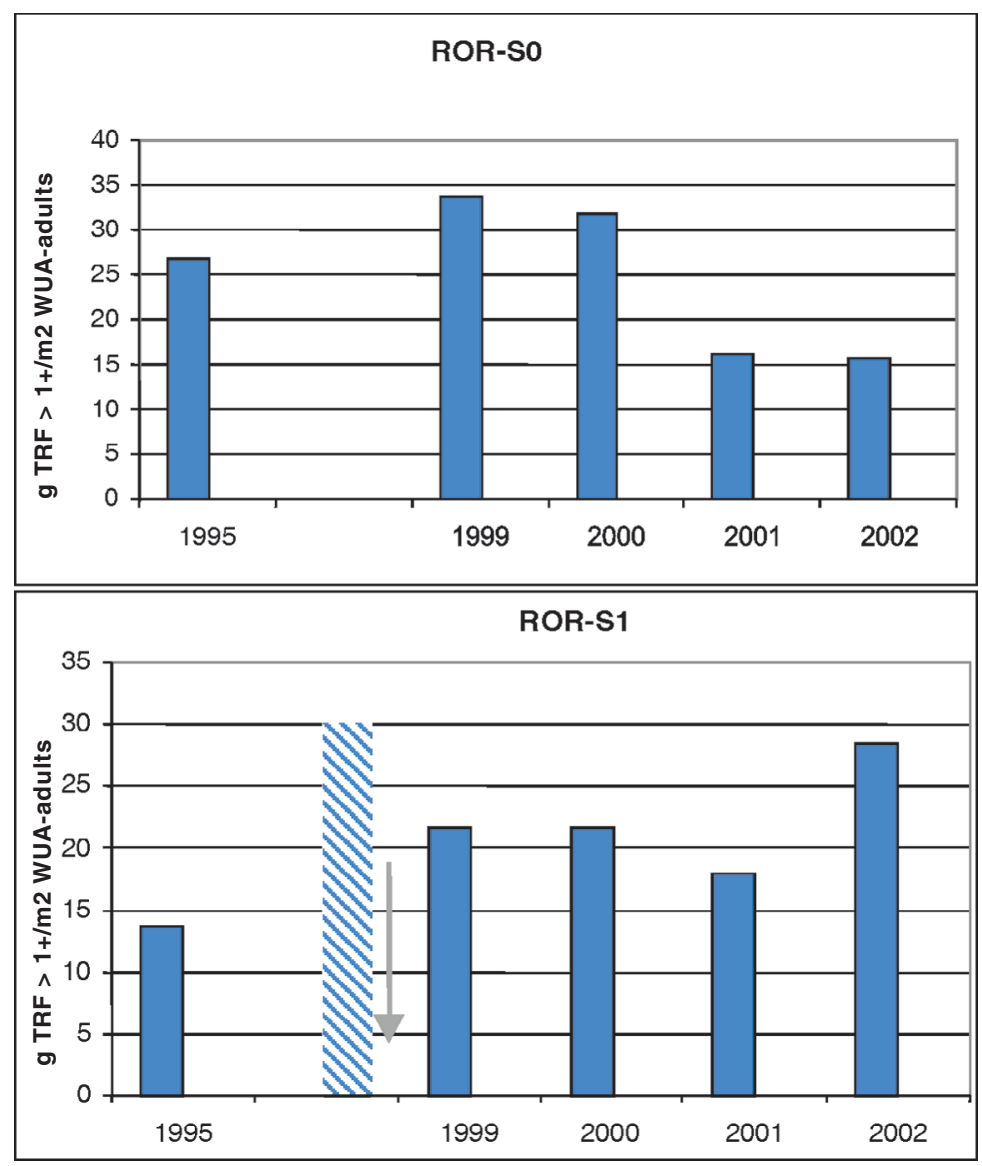

Fig. 11. - Site of Rory - Occupancy rates for adults from 1995 to 2002 - Comparison between reference site and site in the by-passed section

Table 1. - Site of Rory - Surplus of juveniles compared to the number of spills at Pontabouland dam from March to mid-November (the expected number of $1+$ is calculated with a mortality of $50 \%$ from fry stage to juvenile stage)

\begin{tabular}{|c|c|c|c|c|c|}
\hline & & 1999 & 2000 & 2001 & 2002 \\
\hline Number of 0+ & ind/100m & 13.1 & 48.4 & 43.3 & 99.8 \\
\hline Number of 1+ expected & ind/100m & & 6.55 & 24.2 & 21.65 \\
\hline Number of 1+ during inventory & ind/100m & & 15.9 & 52.8 & 24.2 \\
\hline Surplus of 1+ & ind/100m & & 9.4 & 28.6 & 2.6 \\
\hline spills at Pontabouland dam & nr of days & & 15 & 78 & 6 \\
\hline
\end{tabular}



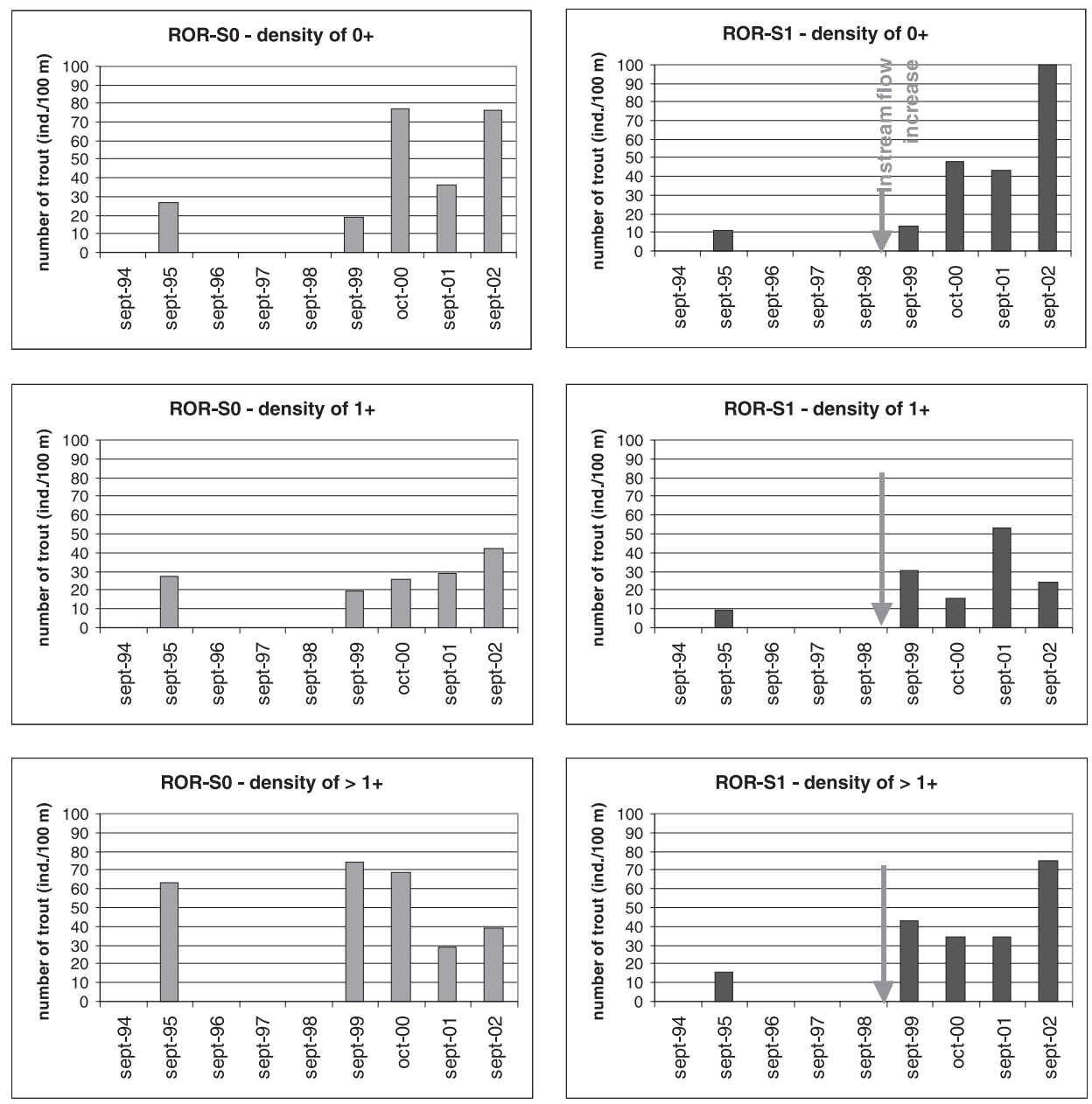

Fig. 12. - Site of Rory - Number of trout in three life stages $(0+, 1+$ and $>1+)$ for each inventory at both study sites

gration of young trout): the greater the number of days of overflow, the greater the surplus of juveniles.

The high densities of $1+$ individuals found in 1999 and 2001 correspond to major overflow episodes (Table 2). Similarly, flooding in 1998 may have caused the arrival of juveniles which would explain the considerable adult biomass found in 1999, as compared with 1995.

A specific study of the spawning grounds throughout the study area shows that conditions for reproduction are relatively poor. In particular, the percentage of the particle sizes 
Table 2. - Site of Rory - Number of days with overflow and higher flow observed (from March to September)

\begin{tabular}{|l|c|c|c|c|c|c|c|c|c|}
\hline & 1994 & 1995 & 1996 & 1997 & 1998 & 1999 & 2000 & 2001 & 2002 \\
\hline Number of days & 53 & 26 & 6 & 0 & 20 & 62 & 15 & 78 & 6 \\
\hline Higher flow observed & 12 & 9,03 & 10,54 & & 22,1 & 25,29 & 13,6 & 16,27 & 13,15 \\
\hline
\end{tabular}

favorable to reproduction (gravel and small cobbles of 0.2 to $5 \mathrm{~cm}$ in diameter), on average $1.5 \%$ for the 4 years of monitoring in the bypassed section, is low: for the purpose of comparison, the average percentage found in the Pyrenees (Delacoste, 1995 ) is from 3 to $4 \%$. These percentages correspond to a mean surface area favorable to reproduction of $14 \mathrm{~m}^{2} / 100 \mathrm{~m}$ of river on the Lignon, as compared with $40 \mathrm{~m} 2 / 100 \mathrm{~m}$ in the Pyrenees.

The habitat at the upstream reference site is also very poor for reproduction, but incoming juveniles may compensate for this poor local recruitment. In the bypassed section, on the other hand, the poor breeding conditions may explain the low occupancy rates found, particularly in 1995 following several years with no major flooding. From 1999 to 2002, the river appears to be repopulated in proportion to the gain in habitat, probably thanks to the almost annual overflow episodes which compound natural recruitment.

Gain in WUA and impact of flooding on the post-emergence phase: PontHaut. The second microhabitat study conducted in 2002 showed that, unlike the habitat in the bypassed section, the physical habitat of the Roizonne at reference site PON-SO had significantly changed between 1995 and 2002: WUA during low-water periods in 2002 was practically half what it had been in 1995 .

Rate of occupancy for this site is therefore calculated for 1994 using the WUA for adults estimated during the 1995 measurement survey; that
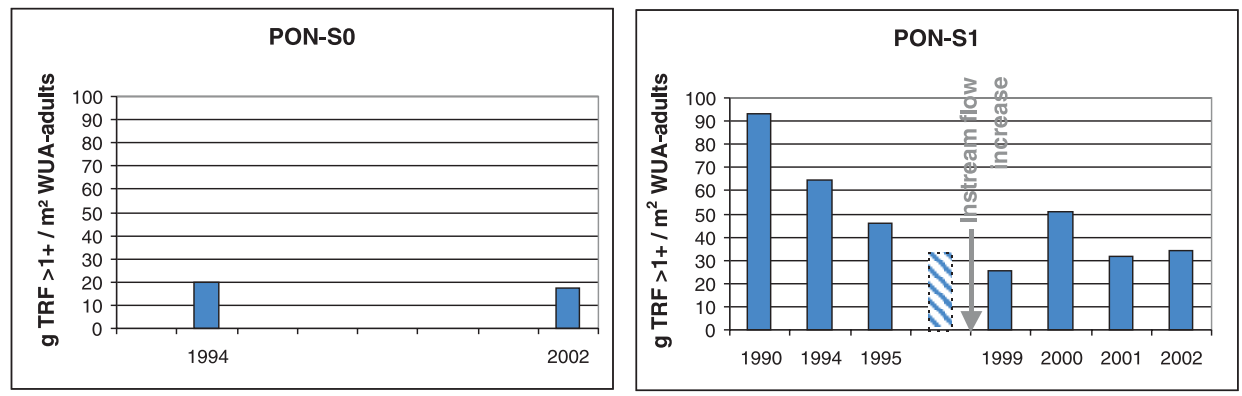

Figure 13. - Site of Pont-Haut - Occupancy rates for adults from 1995 to 2002 - Comparison between reference site and site in the by-passed section 
of 2002, using the WUA for adults estimated during the 2002 survey (figure 13). These relatively low figures are very close: the adult biomass has decreased in proportion to the potentially available habitat. The occupancy rates are higher in the bypassed section than upstream. The trout appear to make better use of the available habitat. Because we have no inventories between 1995 and 1999, the hatched bar corresponds for the purpose of comparison - to a rate calculated using the adult trout biomass observed in 1999 and the WUA for adults before the increase in instream flow. From 1990 to 1995 , the decrease in biomass in the bypassed section (PON-S1) parallels a drop in the occupancy rate. The change in minimum instream flow in 1999 results in an increase in available WUA for adult trout (some $40 \%$ more between $M / 40$ and $M / 10$ ). Because the trout population does not react immediately to the new local carrying capacity, there is first a decline in the rate of occupancy. It rises in 2000 to around $50 \mathrm{~g} / \mathrm{m}^{2}$ of WUA. This rate is relatively high, though lower than what it may have been in 1994. It drops again to around $30 \mathrm{~g} / \mathrm{m}^{2}$ of WUA in 2001 and 2002.
Figure 14 shows the evolution in density for each age class and that of the different cohorts.

The $0+$ densities vary widely, in both the upstream and downstream reaches. They remain very low until 2001 in comparison with the densities observed in 2002. The high occupancy rates in the bypassed section in 2000 most likely correspond to good recruitment in 1998 (if we compare with the number of juveniles observed in 1999).

In fact, with the exception of 1998 and especially 2002, all years corresponding to the inventories had major flooding in the post-emergence period (between March and May). If for this period we choose the threshold suggested by Resh and al (1988) as the flow level that is disturbing for this stage of development, i.e. mean discharge +2 standard deviations (Capra et al, 2003), table 3 gives the number of days on which this threshold discharge of $6.5 \mathrm{~m}^{3} / \mathrm{s}$ is exceeded each year during the period.

The low adult densities observed in 2001 and 2002 can be explained by low recruitment during the period of monitoring.

We can clearly see, at this site, the importance of hydrological events,

Table 3. - Site of Pont-Haut - Number of days with discharge greater than $6.4 \mathrm{~m} 3 / \mathrm{s}$ at each study site over the period 1994-2002

\begin{tabular}{|l|c|c|c|c|c|c|c|c|c|}
\hline & 1994 & 1995 & 1996 & 1997 & 1998 & 1999 & 2000 & 2001 & 2002 \\
\hline PON-S0 & 37 & 36 & 12 & 8 & 6 & 37 & 26 & 36 & 0 \\
\hline PON-S1 & 10 & 20 & 0 & 17 & 0 & 23 & 8 & 8 & 0 \\
\hline
\end{tabular}



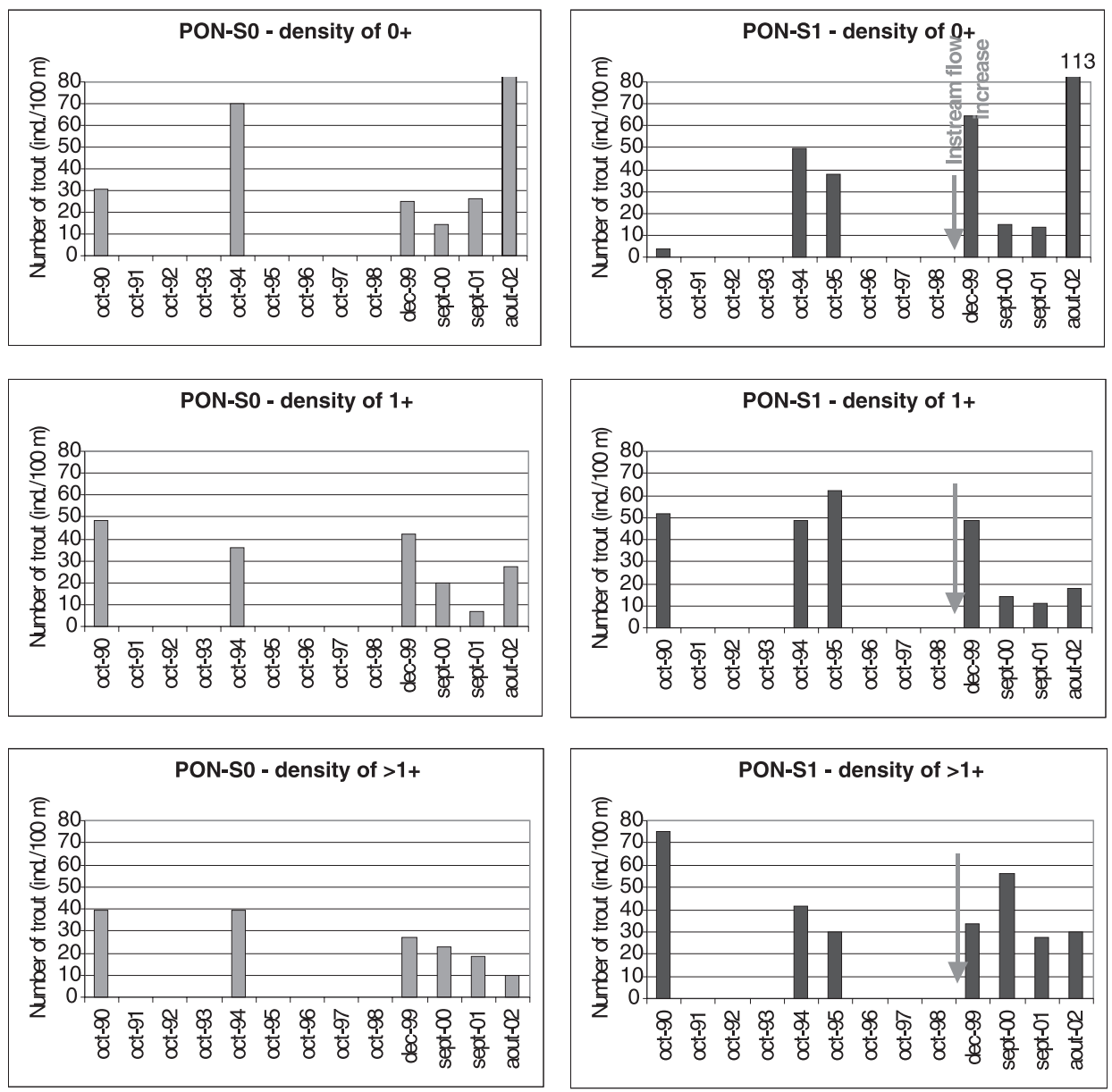

Figure 14. - Site of Pont-Haut - Number of trout in three life stages $(0+, 1+$ and $>1+)$ for each inventory at both study sites

which explain the drop in occupancy rate observed in the bypassed section in 2001 and 2002. The impact of the increase in minimum instream flow is significantly masked by this phenomenon of fry mortality at the time of spring flooding.
Gain in WUA and fish stock management: Saint Georges. At reference site STG-S0, the rates of occupancy of the physical habitat are high (up to $70 \mathrm{~g} / \mathrm{m}^{2}$ of WUA), except in 1999 (Figure 15). The rates observed at STG$\mathrm{S} 1$ in the bypassed section are markedly lower. 

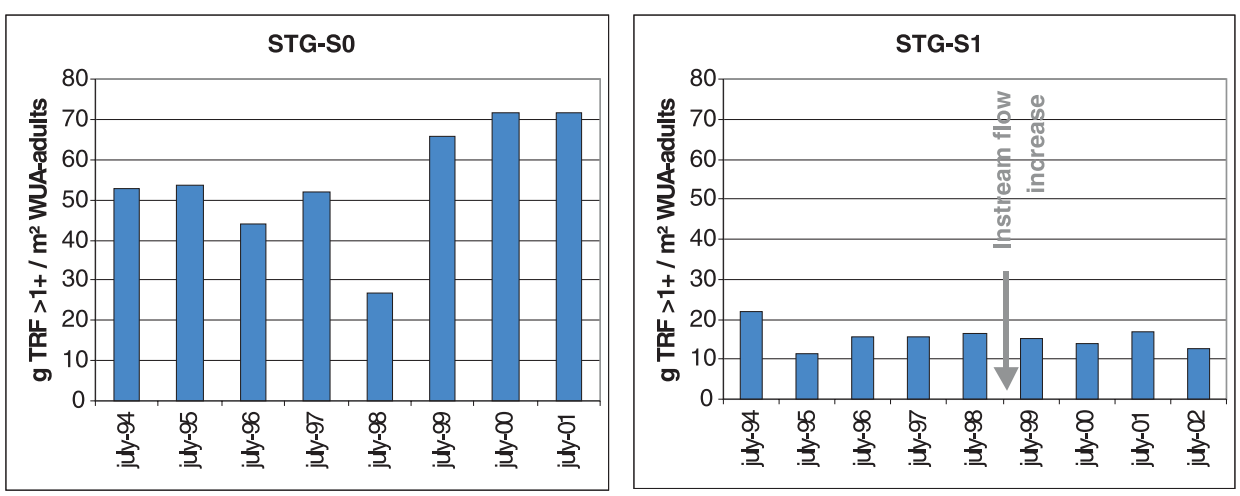

Fig. 15. - Site of St Georges - Occupancy rates for adults from 1995 to 2002 - Comparison between reference site and site in the by-passed section

At this site, the change in the minimum instream flow in 1998 led to a definite increase in WUA available to adult trout (around 43\% more between $\mathrm{M} / 40$ and $\mathrm{M} / 12$ ). The trout population does not react strongly to the new local carrying capacity and the occupancy rates remain very low in comparison with both the reference reach and averages for French rivers.

Figure 16 shows the evolution in density for each age class and that of the different cohorts. The significant fluctuations in $0+$ densities are due either to flooding or to operation of power installations further upstream. These fluctuations do not directly im- pact the 1+ age class, whose densities are equal to or higher than those of the $0+$ in the preceding year. Influxes of juveniles are found, as at the Rory site, most certainly with overflow into the bypassed section at Saint Georges. However, the major fluctuations in numbers of juvenile are not found among the adults, whose numbers remain quite stable.

The results of the halieutic survey conducted at the site are summarized in Table 4.

While angling in the bypassed section is moderate (though higher than in the reference reach - 250 hours per kilometer per year, compared with

Table 4. - Site of St Georges - Halieutic survey

\begin{tabular}{|l|c|c|c|c|c|c|}
\hline & \multicolumn{3}{|c|}{ STG-S0 } & \multicolumn{3}{c|}{ STG-S1 } \\
\hline & $\mathbf{2 0 0 0}$ & $\mathbf{2 0 0 1}$ & $\mathbf{2 0 0 2}$ & $\mathbf{2 0 0 0}$ & $\mathbf{2 0 0 1}$ & $\mathbf{2 0 0 2}$ \\
\hline Catch per unit effort rate (trout / hour) & 0.70 & 0.70 & 0.62 & 0.60 & 0.57 & 0.61 \\
\hline Angling (number of hours / km / year) & 169 & 103 & 128 & 303 & 188 & 258 \\
\hline Total number of fished trout / km / year & 118 & 72 & 79 & 182 & 107 & 157 \\
\hline
\end{tabular}



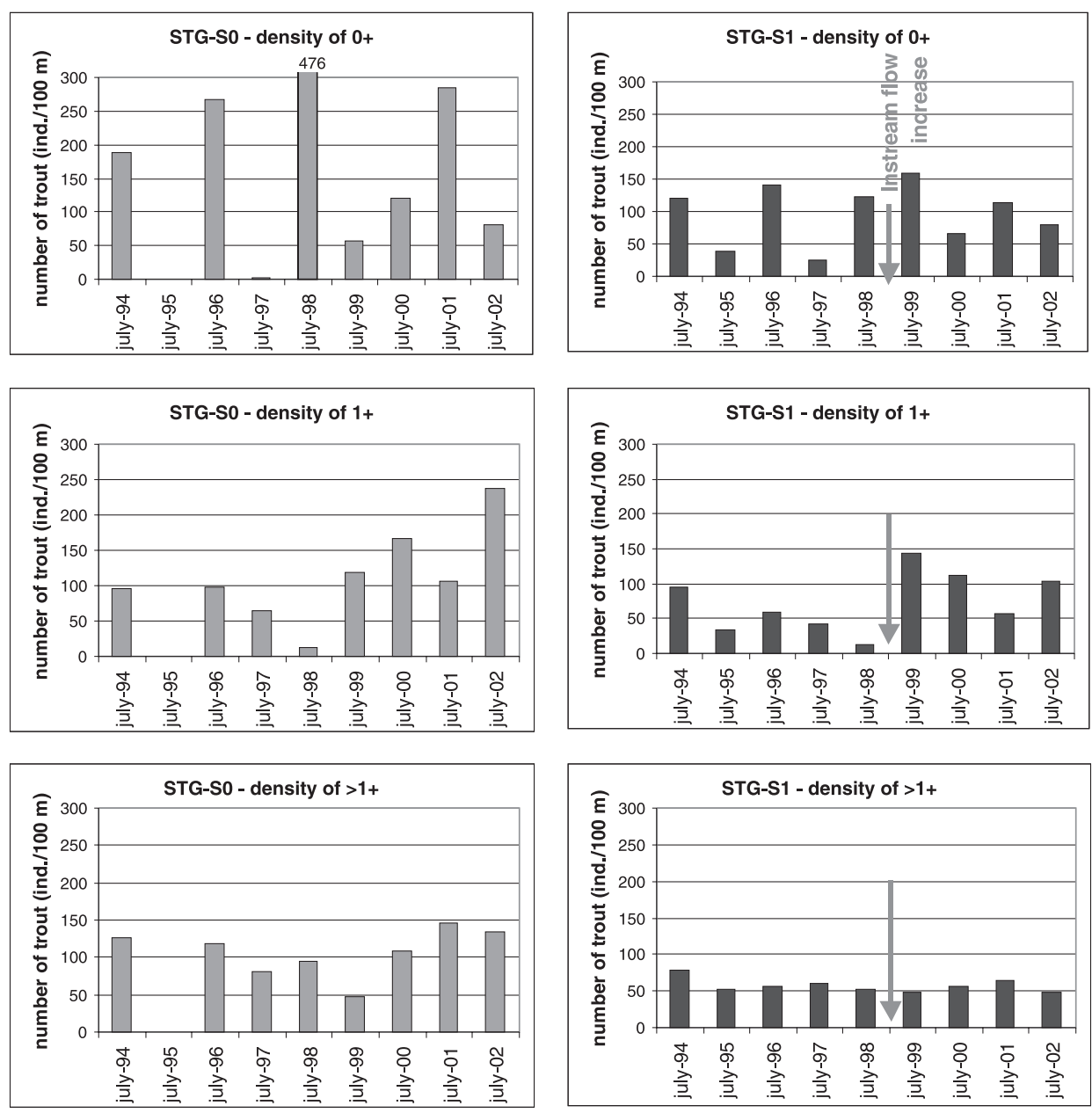

Fig. 16. - Site of St Georges - Number of trout in three life stages $(0+, 1+$ and $>1+)$ for each inventory at both study sites

133 hours upstream), the catch per unit effort rates fall within the higher range of those observed in France (0.6 trout per hour of fishing, compared with a value for all of France which varies from 0.2 to 0.8 ). The number of trout captured per kilometer of river per year is equal on average to
150 in the bypassed section, as against 90 in the reference section. We might also note that the percentage of trout fished at site STG-SO is around $23 \%$ of the stocks in the area, as against $8 \%$ at the reference site. This strong impact of fishing may be a limiting factor for the adult trout popu- 
lation and may explain the low occupancy rates in this reach which is also relatively isolated from its environs.

\section{DISCUSSION}

Validation of the relationships between habitat and fish populations is one of the most challenging tasks in the field of coupled physical/biological modeling. It is also one of the most controversial aspects of the IFIM methodology (Mathur et al, 1985; Orth and Maughan, 1986; Shirvell, 1986; Scott and Shirvell, 1987; Orth, 1987; Gore and Nestler, 1988; Pouilly and Souchon, 1995; Castelberry et al, 1996).

It is nonetheless crucial to attempt to reproduce real observations of the evolution of fish populations over time in order to make better use of the method for empirical purposes. Very few studies in the literature today have attempted to analyze the relationship between the physical habitat, measured by PHABSIM in terms of WUA versus discharge, and fish biomass (i.e. representing one of the aggregations of the data on the population level) (Bovee, 1982; 1985; 1988; Orth and Maughan, 1982; Souchon et al, 1989; Jowett, 1993; Baran, 1995). In reality, not enough long-term monitoring of fish populations has yet been done to analyze these relationships properly. There is general agreement on this on the part of the users of IFIM (Bovee, 1985; Pouilly and Souchon, 1995), its detractors (Castelberry et al, 1996) who advocate adaptive management and researchers working on population dynamics models (Jager, 2003).

The present study, described at the time it was begun by Merle and Eon., 1996, represented an attempt to gather data so as to understand this complex link between habitat and population. The experimental protocol was based on 4-year monitoring at reference sites not influenced by hydropower installations and at sites with regulated discharge, following implementation of a change in minimum instream flow (increased from $1 / 40$ to $1 / 10$ of the mean annual discharge on average). To the best of our knowledge, only Studley et al (1995) had previously conducted the same type of experiment on a comparable scale.

The working hypothesis is that the physical habitat, measured in terms of WUA versus discharge, is the central factor which limits a population.

The initial results presented here bear on a study of 3 streams out of a total of 8 which have been monitored. The trends found indicate that the habitat estimated on the basis of monthly low-water period discharge in non-regulated reaches, or minimum instream flow in bypassed sections, indeed determines a carrying capacity which is meaningful essentially when expressed as a year-toyear average.

Complete colonization by a population of this carrying capacity (i.e. a simple relationship for biomass versus limiting habitat) is, on the other 


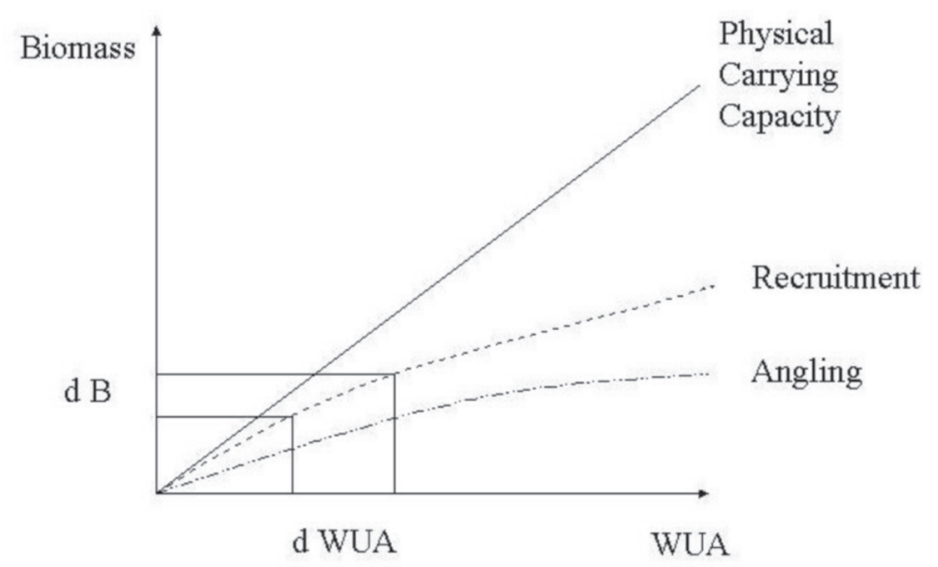

Fig. 17. - Relationship of biomass versus WUA as a function of different factors

hand, extremely variable and dependent on other factors (Figure 17). It depends on phenomena described in the literature but often measured independent of any analysis of the habitat according to a PHABSIM protocol.

\section{Comparison among the sites}

In no case here was evidence found of limitation due to temperature (maximum exceptional temperatures never exceeded $18.5^{\circ} \mathrm{C}$ ) or water quality. On the other hand, the most marked effects common to all sites which adversely affect populations relate to strong spring discharge, which significantly limits recruitment and whose effects are felt for several years, both at reference sites and at sites with regulated discharge. These phenomena are widely described in the literature, with mechanisms that relate to modifications in redds and entrainment of $0+$ individuals shortly after emergence (Nehring and Anderson, 1993).

In this regard, Cattaneo et al (2002) have shown surprising similarities on several streams in a single hydrographic basin, with strong spring floods consistently being accompanied by tendencies to low recruitment.

\section{Description of individual sites}

On the Lignon, we find that the population reacts positively to the increase in minimum discharge and in habitat. The year-to-year average population in the regulated reach is relatively small in comparison with the potential carrying capacity. This is a site where the measured potential 
spawning habitat is limited, and diminishes over the period of monitoring. The low level of local recruitment is sometimes counterbalanced by the arrival of individuals from upstream, over the dam; this phenomenon is all the more marked when there is strong flooding and therefore significant spillage. This interesting phenomenon of compensation shows that even a site at which considerable monitoring is being done may be insufficient for integration of the full spatial reality of the dynamics of a population like trout. Trout not only migrate once they reach adult phase but also cover very long distances in the $1+$ stage, as has recently been demonstrated (Fausch et al., 1995).

On the Roizonne, on the contrary, we find a drop in biomass after the increase in discharge; this decline is concomitant with the overall phenomenon of mediocre recruitment linked to consistently strong spring discharge for several years after the increase in minimum instream flow. Equally interesting is the fact that the available habitat is better utilized in the bypassed section than at the reference site. This may indicate two mechanisms at work: a deficit of breeders, unable to cross over the dam into the reference reach, compounded by an unmitigated effect of frequent flooding, in comparison with the bypassed section which receives floodwaters diminished by the flow diverted through the turbines.

On the Aude, we find almost identical biological conditions before and after the increase in instream flow.
The trout biomass per unit of potential habitat is low in the bypassed section compared with the reference site. This site is favorable to trout reproduction. The negative factor here is fishing, in a sector which is very accessible and therefore extensively fished.

\section{CONCLUSION}

These studies show that, to use the microhabitat method properly to predict fish biomass, we must integrate the impact of factors not taken into account in the model. When we adopt a more comprehensive approach, it is always possible to explain the situations observed by a characteristic of the populations found in the literature, with the impact of the habitat as measured by Phabsim taken as one of the limiting factors. The studies also show that we must take care when making generalizations about the biological impact of minimum instream flow, given the considerable variations in regional and local conditions.

The benefit of the method lies in the analysis of the sensitivity of habitat conditions (particularly depth and velocity) to modifications in discharge, as has always been clearly described by its developers, whose original intent to keep the model simple must be respected.

Moving from this to the scale of an entire population requires additional data and a real analysis of the population dynamics (Gouraud et al, 2003 - 
at this conference) using appropriate techniques (Williams, 1984; Cheslack and Jacobson, 1990; Van Winkle et al, 1996; Williamson et al, 1998; Jessup, 1998; Sabaton et al, 1998). However, if a model is to provide more realism in biological terms, it necessarily gains in complexity and therefore becomes more difficult to calibrate.

\section{REFERENCES}

Baran, P. 1995. Analyse de la variabilité des abondances de truites communes (Salmo trutta L.) dans les Pyrénées centrales françaises. Thèse 3ème cycle Sciences Agronomiques, Institut National Polytechnique de Toulouse, pp.132.

Bovee, K.D. 1978. Probability of use criteria for the family salmonidae. Instream Flow Information Paper n०4, U.S. Fish and Wildlife Service, Fort Collins, Colorado, USA

Bovee, K.D. 1982. A guide to stream habitat analysis using the instream flow incremental methodology. Instream Flow Information Paper $n^{\circ} 12$, U.S. Fish and Wildlife Service, Fort Collins, Colorado, USA

Bovee, K.D. 1985. Evaluation of the effects of hydropeaking on aquatic macroinvertebrates using PHABSIM. Proceedings of the symposium Small Hydropower Fisheries, Olson FW, White RG, and Hamre RH (eds.). American Fisheries Society, Western Division, Bethesda, Maryland; 236-241.

Bovee, K.D. 1988. Use of the instream flow incremental methodology to evaluate influences of microhabitat variability on trout populations in four Colorado streams. Proceedings of the Western Division American Fisheries Society, Albuquerque, NEWMEXCOUSA.
Capra, H. 1995. Amélioration des modèles prédictifs d'habitat de la truite fario: Echelles d'échantillonnage - Intégration des chroniques hydrologiques. Diplôme de Doctorat, Université Claude Bernard, Lyon I.

Capra, H., C. Sabaton, V. Gouraud, Y. Souchon, P. Lim 2003. A population dynamics model and habitat simulation as a tool to predict brown trout demography in natural and by-passed stream reaches. River Research and Applications, 19: 551-568.

Castelberry, D.T., J.J. Cech, Jr, D.C. Erman, D. Hankin, M. Healey, G.M, Kondolf, M. Mangel, M. Mohr, P.B. Moyle, J. Nielsen, T.P. Speed, J.G. Williams 1996. Uncertainly and instream flow standards. Fisheries, 21 : 20-21.

Cattanéo, F., N. Lamouroux, P. Breil, H. Capra 2002. The influence of hydrological and biotic processes on brow trout (Salmo trutta) population dynamics. Canadian Journal of Fisheries and Aquatic Sciences, 59: 12-22.

Cheslak, E.F., A.S. Jacobson 1990. Integrating the instream flow incremental methodology with a population response model. Rivers, 1(4) "264-288.

Delacoste, M. 1995. Analyse de la variabilité spatiale de la reproduction de la truite commune (Salmo trutta L.) Etude à l'échelle du micro et du macrohabitat dans 6 rivières des Pyrénées centrales. Thèse 3ème cycle Sciences Agronomiques, Institut National Polytechnique de Toulouse.

Fausch, K.D., M.K. Young 1995. Evolutionarily significant units and movement of resident stream fishes: a cautionary tale. American Fisheries Society Symposium, 17: 360-370

Gore, J.A, J.M. Nestler 1988. Instream flow studies in perspective. Regulated Rivers: Research and Management, 5: 129-138.

Gouraud, V., C. Sabaton, H. Capra 2003. Role of habitat variability in trout popu- 
lation dynamics: Application of a dynamic population model on three French rivers. Paper presented at International IFIM Users Workshop, Office of Conference Services, Colorado State University, Fort Collins, USA

Ginot, V., Y. Souchon, H. Capra, P. Breil, S. Valentin 1998. Logiciel EVHA. Evaluation de l'habitat physique des poissons en rivière (version 2.0.). Guide méthodologique, Cemagref Lyon BEA/ LHQ et Ministère de l'Environnement, Dir. de l'Eau, Paris, France

Jessup, B.K. 1998. A strategy for simulating brown trout population dynamics and habitat quality in an urbanizing watershed. Ecological modelling, 112: 151-167.

Lauters, F. 1995. Impacts sur l'écosystème aquatique de la gestion par éclusées des ouvrages hydroélectriques Etude de quelques cours d'eau et analyse des phénomènes mis en jeu. Diplôme de Doctorat. Université Paul Sabatier, Toulouse, France.

Mathur, D., W.H. Bason, E.J. Purdy, C.A. Silver 1985. A critique of the instream flow incremental methodology. Canadian Journal of Fisheries and Aquatic Sciences, 42: 825-831.

Merle, G., J. Eon 1996. A full-scale test to validate the contribution of the IFIM procedure in the choice of a guaranteed flow downstream hydrostations. Proceedings of the Second International Symposium on Habitat Hydraulics, Quebec, Canada.

Milhous, R. T. M. A. Updike and D. M. Schneider 1989. Physical Habitat Simulation System Reference Manual Version II. Instream Flow Information Paper $n^{\circ}$ 26, U.S. Fish and Wildl. Serv. Biol. Rep. 89(16), v.p. Fort Collins, Colorado, USA.

Nehring, R.B., R.M. Anderson 1993. Determination of Population-limiting Critical Salmonids Habitats in Colorado Streams Using the Physical Habitat Simulation System. Rivers, 4(1): 1-19.
Orth, D.J., 1987. Ecological considerations in the development and application of instream flow-habitat models. Regulated River. Research and Management, 1, 171-181.

Orth, D.J., Maughan, O.E. 1982. Evaluation of the incremental methodology for recommending instream flows for fisheries. Transactions of the American Fisheries Society 111, 413-445.

Orth, D.J., O.E. Maughan 1986. In defense of the instream flow incremental methodology. Canadian Journal of Fisheries and Aquatic Sciences, 43: 1092-1093.

Pouilly, M., Y. Souchon 1995. Méthode des microhabitats: validation et perspectives (Microhabitat methodology: validation and perspectives). Bull. Fr. Pêche et Piscic., 337/338/339: 329336.

Resh, V. H., A. V. Brown, A.P. Covich, M.E. Gurtz, H.W. Li, G.W. Minshall, S.R. Reice, A.L. Sheldon, J.B. Wallace, R.C. Wissmar 1988. The role of disturbance in stream ecology. Journal of North American Benthological Society, 7: 433-455.

Sabaton, C., L, Siegler, V. Gouraud, J.L. Bagliniere, S. Manne 1997. Presentation and first applications of a dynamic population model for brown trout (Salmo trutta L.): aid to river management. Fisheries Management and Ecology, 4: 425-438.

Scott, D., C.S. Shirvell 1987. Critique of the instream flow incremental methodology and observations on flow determination in New Zealand. Regulated Streams: Advances in Ecology, Volume (no): $27-43$. Or maybe this is a chapter in a book?

Shirvell, C.S. 1986. Pitfalls of physical habitat simulation in the instream flow incremental methodology. Canadian Technical Report of Fisheries and Aquatic Sciences, 1460.

Souchon, Y., F. Trocherie, E. Fragnoud, C. Lacombe 1989. Les modèles numéri- 
ques des micro-habitats des poissons: application et nouveaux développements. Revue des sciences de l'eau, 2: 807-830.

Van Winkle, W., Y. Jager, B. Holcomb 1996. An Individual-Based Instream Flow Model for Coexisting Populations of Brown and Rainbow Trout. Interim Report. Prepared by Lockheed Martin Energy Systems Inc. for Electric Power Research Institute, Pacific Gas \& Electric Company, and Southern California Edison Company. Layaffette, California, Electric Power Research Institute.
Williams, F.M. 1984. A fish population model for instream flow assessment. Technical report A-059-PA, Institute for Research on Land and Water Resources, the Pennsylvania State University.

Williamson, S.C., J.M. Bartholow, C.B Stalnaker 1993. Conceptual model for quantifying pre-smolt production from flow-dependent physical habitat and water temperature. Regulated Rivers: Research \& Management, 8: 15-28. 


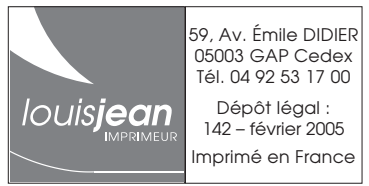


